\title{
Stimulation of locomotor activity following injection of dopamine into the nucleus accumbens
}

Recently we have observed that bilateral injection of ergometrine into the nucleus accumbens of rats results in a strong and long-lasting enhancement of locomotor activity (Pijnenburg, Woodruff \& van Rossum, 1973). This effect was antagonized by low doses of haloperidol and pimozide. The hypothesis was proposed that this enhanced locomotor activity was elicited by a stimulation of dopamine receptors in the nucleus accumbens.

We now report that administration of dopamine directly into the nucleus accumbens of nialamide-pretreated rats produces a pattern of enhanced locomotor activity similar to that seen after ergometrine.

Seven male Wistar rats (200-220 g) were implanted with double barrelled cannulas in each side of the nucleus accumbens (coordinates A 9.4, L 1.2 and $\mathrm{H}-0.6$ according to the atlas of König \& Klippel, 1963). These animals were used for all experiments with 5-8 days between experiments. The animals were subsequently killed and brains were sectioned to determine the position of the cannulas. For details of the experimental procedure see Pijnenburg \& others (1973). Injections were made by means of a $5 \mu 1$ Hamilton syringe with a 31 gauge needle. The injection volume was $0.5 \mu \mathrm{l}$. Dopamine $\mathrm{HCl}$ and (-)-noradrenaline (-)-hydrogen tartrate were dissolved in saline.

Locomotor activity was measured in activity cages, equipped with photoelectric cells and recorded on a cumulative recorder.

The rats were always pretreated with the monoamine oxidase inhibitor nialamide (100 mg kg-1 i.p.) $18 \mathrm{~h}$ before administration of saline, dopamine or noradrenaline. Injection of dopamine $(5 \mu \mathrm{g})$ to each side of the nucleus produced a strong enhancement of locomotor activity, which started in 5 animals within 10 min of injection and lasted for up to $4 \mathrm{~h}$, reaching a peak at about $1 \mathrm{~h}$ returning to 0 over the next $3 \mathrm{~h}$ with the most rapid decline over the last $30 \mathrm{~min}$. In two rats, in which the injection site was found to be at the border of the nucleus accumbens, stimulation of locomotor activity started after 20 and $30 \mathrm{~min}$ respectively and failed to reach the level seen in the other rats. This is probably the reason for the large variability in the results (see Table 1).

Injection of noradrenaline $(5.0 \mu \mathrm{g})$ into each side of the nucleus accumbens of the same rats produced enhanced locomotor activity in 5 of the 7 animals but this was

Table 1. The effect on locomotor activity of injections of dopamine and noradrenaline into each side of the nucleus accumbens of the rat. Nialamide $100 \mathrm{mg} \mathrm{kg}^{-1}$ was given $18 \mathrm{~h}$ before the injection of dopamine or noradrenaline $(\mathrm{n}=$ number of experiments).

\begin{tabular}{|c|c|c|c|c|c|c|c|}
\hline & \multicolumn{2}{|r|}{ Dose } & $\mathbf{n}$ & \multicolumn{4}{|c|}{ 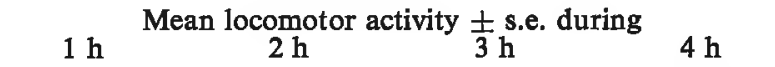 } \\
\hline $\begin{array}{l}\text { Saline } \\
\text { Dopamine } \\
\text { Noradrenaline }\end{array}$ & $\cdots$ & $\begin{array}{l}5.0 \\
1-0 \\
5.0\end{array}$ & $\begin{array}{l}7 \\
7 \\
7 \\
7\end{array}$ & $\begin{array}{c}138 \pm 28 \\
3652 \pm 1010^{\mathrm{a}} \\
1344 \pm 463^{\mathrm{d}} \\
580 \pm 232^{\mathrm{d}}\end{array}$ & $\begin{aligned} 43 & \pm 6 \\
4672 & \pm 892^{b} \\
784 & \pm 261^{d} \\
1012 & \pm 413^{d}\end{aligned}$ & $\begin{array}{c}35 \pm 10 \\
3884 \pm 889^{b} \\
185 \pm 58^{d} \\
689 \pm 30^{d}\end{array}$ & $\begin{aligned} 13 & \pm 5 \\
2012 & \pm 627^{\mathrm{c}} \\
67 & \pm 25 \\
408 & \pm 18^{\mathrm{d}}\end{aligned}$ \\
\hline
\end{tabular}

${ }^{a} P<0.02$ both with respect to saline and noradrenaline $5.0 \mu \mathrm{g}$.

b $P<0.01$ both with respect to saline and noradrenaline $5.0 \mu \mathrm{g}$.

c $P<0.02$ with respect to saline, $P<0.05$ with respect to noradrenaline $5.0 \mu \mathrm{g}$.

d $P<0.05$ with respect to saline.

Statistical significance calculated according to Student's $t$-test for paired comparison. 
significantly less than after the dopamine $(5.0 \mu \mathrm{g})$ and started after $30-40 \mathrm{~min}$ and lasted about $4 \mathrm{~h}$. The 2 rats with offset injection sites showed no stimulation of locomotor activity after noradrenaline.

Even a dose of $1.0 \mu \mathrm{g}$ of dopamine was effective in 5 of the 7 rats who responded with enhanced locomotor activity within $10 \mathrm{~min}$. The degree of motor activity, which was highest during the first hour, was less than after the $5.0 \mu \mathrm{g}$ dose and lasted for about 2-3 h (see Table 1). The 2 animals with offset injection sites did not respond. Injections of saline were ineffective.

Thus, stimulation of dopamine receptors in the nucleus accumbens results in enhanced locomotor activity. The behavioural pattern showed the same characteristics as seen after injection of ergometrine, i.e. continuous exploring activity, except that the time for the appearance of locomotor stimulation was shorter.

This finding favours the assumption that ergometrine has dopamine-stimulating properties in the rat brain. This is in agreement with observations on some other ergot-derivatives. For instance, it was found by Stone (1973) that agroclavine produced "stereotyped" sniffing and gnawing behaviour. Corrodi, Fuxe \& others (1973) found that ergocornine and 2-Br- $\alpha$-cryptine (CB154) mimicked the action of apomorphine in rats with a unilateral 6-hydroxydopamine-induced degeneration of the nigro-neostriatal dopamine pathway and produced a decrease in the dopamine turnover in the neostriatum and the limbic system; they concluded that the main action of these drugs was a direct dopamine receptor stimulation of long duration.

Several studies have indicated that dopamine might play an important role in the motor stimulation seen after injection of psychomotor stimulant drugs (van Rossum \& Hurkmans, 1964; Maj, \& Grabowska \& Gajda, 1972; Andén, Strömbom \& Svensson, 1973). Although we would not exclude the role of noradrenaline, it is possible that these drugs exert their effect in part via the dopamine system in the nucleus accumbens.

Bilateral injection of dopamine into the caudate nucleus of nialamide-pretreated rats did not result in such a strong locomotor activity. Although with doses of 10 and $50 \mu \mathrm{g}$ dopamine there was a slight to moderate increase of motor activity, the predominant feature was stereotyped sniffing behaviour, which appeared 30-40 min after the injection (D. Malec, unpublished). This was not seen in the present experiments which provide evidence that the mesolimbic dopamine system with cell bodies in the A 10 group (classification according to Dahlström \& Fuxe, 1965) and nerve terminals in the nucleus accumbens and tuberculum olfactorium (Andén, Dahlström \& others, 1966; Arbuthnott, Crow \& others, 1970; Ungerstedt, 1971) is functionally different from the nigrostriatal dopamine system.

This work was supported by grants from the Foundation for Medical Research FUNGO, the Netherlands. Nialamide was generously supplied by the firm Pfizer, Brussels. The excellent technical assistance of Mr. W. M. Honig is gratefully acknowledged.

Department of Pharmacology,
University of Nijmegen,
Medical School,
Geert Grooteplein Noord 21,
Nijmegen, The Netherlands.

A. J. J. PiJNenburg

J. M. VAN Rossum

July 16,1973

\section{REFERENCES}

Andén, N-E., Dahlström, A., Fuxe, K., Larsson, K., Olson, L. \& Ungerstedt, U. (1966). Acta physiol. scand., 67, 313-326.

Andén, N-E., Strömвom, U. \& Svensson, T. H. (1973). Psychopharm., 29, 289-298. 
Arbuthnott, G. W., Crow, T. J., Fuxe, K., Olson, L. \& Ungerstedt, U. (1970). Brain Res., 24, 471-483.

Corrodi, H., FuXe, K., Hökfelt, T., Lmbrink, P. \& Ungerstedt, U. (1973). J. Pharm. Pharmac., 25, 409-412.

Dahlström, A. \& FuXz, K. (1965). Acta physiol. scand., 62, Suppl., 232, 1-55.

KöNIG, J. F. R. \& KLIPPEL, R. A. (1963). The rat brain. Baltimore: Williams and Wilkins.

MaJ, J., Grabowska, M. \& Gajda, L. (1972). Eur. J. Pharmac., 17, 208-214.

Rossum, J. M. van \& Hurkmans, J. A. Th. M. (1964). Int. J. Neuropharm., 3, 227-239.

PisnenburG, A. J. J., Woodrupf, G. N. \& Rossum, J. M. van (1973). Brain Res., in the press.

Stone, T. W. (1973). Archs int. Pharmacodyn. Thér., 202, 62-65.

UNGERSTEDT, U. (1971). Acta physiol. scand., 82, suppl. 367, 1-48. 